$\begin{array}{ll}\text { Received } & : \text { 20 June } 2019 \\ \text { Revised } & : \text { 27 June } 2019 \\ \text { Accepted } & : \text { 29 June } 2019 \\ \text { Published } & : \text { 30 June } 2019\end{array}$

\title{
Development of Indonesian Language Learning Video Media Based on Multicultural Education for Establish Anti-Ethnic Collection at High School Levels in Singkawang City
}

\author{
Sri Mulyani ${ }^{1, a)}$, Rini Setyowati ${ }^{1, b)}$, Heru Susanto ${ }^{1, \mathrm{c})}$ \\ STKIP Singkawang, Kota Singkawang, Kalimantan Barat, Indonesia \\ E-mail: ${ }^{\text {a) }}$ srimulyani.stkip@ gmail.com, ${ }^{\text {b) }}$ rini1989setyowati@gmail.com, \\ c)anto_eru@yahoo.co.id
}

\begin{abstract}
The objectives of this research are (1) Development of video media for multicultural education-based Indonesian learning to build inter-ethnic harmony at the high school level in Singkawang City and (2) the feasibility of video media for Indonesian language learning based on multicultural education to build inter-ethnic harmony at the high school level in the city. Singkawang. This research is a development study using the 4-D model (Four-D developed by Thiagarajan (2011) which includes the stages of defining, designing, developing, and disseminating). This research was carried out in 1 phase with a duration of 1 year The results showed that (1) The stages of development of the development of Multicultural Education-Based Indonesian Language video media for Building Ethnic Harmony at the High School Level in Singkawang City adopted the step or stage of Thiagarajan (2011) which included the defining stage (define), design, develop, and disseminate (2) The results of the assessment by media experts for all $\mathrm{n}$ scores are 4.1 with good category and suitable for use, then based on the assessment of media experts the mean of all aspects is 4.3 with a very good category so that the material is suitable for use.
\end{abstract}

Keywords: video, multicultural, education, establish anti-ethnic

\begin{abstract}
Abstrak
Tujuan dalam penelitian ini adalah (1) Pengembangan media video Pembelajaran Bahasa Indonesia Berbasis Pendidikan Multikultural untuk Membangun Kerukunan antarEtnis pada Tingkat SMA di Kota Singkawang dan (2) Kelayakan media video Pembelajaran Bahasa Indonesia Berbasis Pendidikan Multikultural untuk Membangun Kerukunan antar Etnis pada Tingkat SMA di Kota Singkawang. Penelitian ini merupakan penelitian pengembangan dengan menggunakan model 4-D (Four-D
\end{abstract}


dikembangkan oleh Thiagarajan (2011) yang meliputi tahap pendefinisian (define), perencanaaan (design), pengembangan (develop), dan penyebaran (disseminate). Penelitian ini dilaksanankan 1 tahap dengan durasi waktu 1 tahun. Hasil penelitian menunjukkan bahwa (1) Tahapan pengembangan Pengembangan media video Pembelajaran Bahasa Indonesia Berbasis Pendidikan Multikultural untuk Membangun Kerukunan antar Etnis pada Tingkat SMA di Kota Singkawang mengadopsi langkah atau tahapan Thiagarajan (2011) yang meliputi tahap pendefinisian (define), perencanaaan (design), pengembangan (develop), dan penyebaran (disseminate) (2) Hasil penilaian oleh ahli media untuk seluruh $\mathrm{n}$ diperoleh rerata skor 4.1 dengan kategori baik dan layak untuk digunakan. Selanjutnya berdasarkan penilaian ahli media Rerata dari keseluruh aspek adalah 4.3 dengan kategori sangat baik sehingga materi layak untuk digunakan.

Kata kunci: video, multicultural, education

\section{PENDAHULUAN}

Indonesia merupakan negara dengan latar belakang budaya, suku, bahasa, dan agama yang sangat beragam. Dalam hal pendidikan Indonesia memerlukan pendekatan dan instrumen yang strategik yang dapat dijadikan sebagai sebuah gerakan nasional untuk mewujudkan persatuan, kesatuan, dan keutuhan bangsa agar menjadi bangsa yang berdaulat dan bermartabat. Salah satu instrumen pendekatannya adalah melalui pendidikan multikultural.

Pendidikan multikultural secara etimologis terdiri dari dua kata yaitu, pendidikan dan multikultural. Pendidikan merupakan proses pengembangan sikap dan tingkah laku, sedangkan multikultural daat diidentikkan dengan keberagaman budaya baik etnis ataupun agama. Andersen dan Cusher (1994) mengatakan bahwa pendidikan multikultural adalah pendidikan mengenai keragaman kebudayaan. Dalam pendidikan multikultural terdapat iga kata kunci yang menandai adanya pendidikan multikultural yaitu; pertama, proses pengembangan sikap dan tata laku, kedua, menghargai perbedaan dan keragaman budaya. Ketiga, penghargaan terhadap budaya lain. Kata kunci tersebut akan menjadi landasan dalam merumuskan konsep Islam dalam memahami pendidikan multikultural.

Beberapa poin penting dari pendidikan multikultural adalah kemampuan guru untuk menanamkan cara hidup menghormati dan toleransi yang ada dalam masyarakat Indonesia yang beragam. Pendidikan multikultural menawarkan satu alternatif pembelajaran yang memberikan ruang pada keberagaman dalam masyarakat, seperti keberragaman etnis, budaya, gender, status sosial, gender, kemampuan umum dan lain sebagainya. Pendidikan multikultural diharapkan dapat membentuk karakter siswa yang humanis, demokrasi, dan plural. Secara spesifik Banks memberikan definisi tentang pendidikan multikultural, yaitu ide, gerakan pembaharuan pendididikan yang tujuannya adalah melibatkan struktur lembaga pendidikan supaya siswa dengan berbagai macam latar belakang akan memiliki kesempatan yang sama untuk mencapai prestasi akademis di sekolah (Banks, 1993).

Banks (1993) mengemukakan empat pendekatan yang mengintegrasikan materi pendidikan multikultural ke dalam kurikulum ataupun pembelajaran di sekolah yang bila dicermati relevan untuk diimplementasikan di sekolah di Indonesia, bahkan pendekatan pertama sudah biasa dilakukan, yaitu:1)Pendekatan kontribusi (the 
contributions approach). Level ini yang paling sering dilakukan dan paling luas dipakai dalam fase pertama dari gerakan kebangkitan etnis. Ciri pendekatan kontribusi ini adalah dengan memasukkan pahlawan-pahlawan dari suku bangsa/ etnis dan bendabenda budaya ke dalam pelajaran yang sesuai. Hal inilah yang sampai saat ini yang dilakukan di Indonesia; 2) Pendekatan Aditif (Aditive Approach). Pada tahap ini dilakukan penambahan materi, konsep, tema, dan perspektif terhadap kurikulum tanpa mengubah struktur, tujuan dan karakteristik dasarnya.

Pendekatan aditif ini sering dilengkapi dengan penambahan buku, modul atau bidang bahasan terhadap kurikulum tanpa mengubahnya secara substansif. 3)Pendekatan Transformasi (the transformation approach). Pendekatan tranformasi berbeda secara mendasar dengan pendekatan kontribusi dan aditif. Pada pendekatan transformasi mengubah asumsi dasar kurikulum dan menumbuhkan kompetensi siswa dalam melihat konsep, isu, tema, dan problem dari beberapa perspektif dan sudut pandang etnis. Bank (1993) menyebut ini proses multiple acculturation sehingga rasa saling menghargai, kebersamaan dan cinta sesama dapat dirasakan melalui pengalaman belajar. 4)Pendekatan Aksi Sosial (the social action approach) mencakup semua elemen dari pendekatan transformasi, namun menambah komponen yang mempersyaratkan siswa membuat aksi yang berkaitan dengan konsep, isu atau masalah yang dipelajari dalam unit.

Kerukunan antar etnis adalah salah satu kunci utama dalam menciptakan persatuan Indonesia, seperti yang tertuang dalam salah satu sila pancasila yaitu sila ketiga. Sikap menghargai dan merasa bahwa perbedaan ini adalah kekayaan bangsa dapat kita tanam mulai sejak pendidikan dasar, dimana peserta didik sudah dapat merasakan sendiri bagaimana perbedaan budaya multikultural di sekolah tempat ia belajar. Kota Singkawang, adalah salah satu kota yang sangat kaya akan perbedaan itu, generasi muyda dengan mudah dapat melihat ada kelenteng atau pekong tua yang letaknya bersebelahan dengan masjid raya, yang bernilai sejarah dan dibangun dipusat kota, dan disini semua itu selain menjadi tempat ibadah, juga merupakan tempat rekreasi. Generasi muda sangat antusias untuk memberitahukan kepada dunia bahwa mereka kaya akan budaya, mereka berbahagia dengan budaya tempat dimana mereka tinggal, mereka bersam-sama dari beberapa etnis terus mencari dan menampilkan yang terbaik agar budayanya dikenal dunia, salah satu contohnya yang sering sekali terlihat akhir-akhir ini yaitu mereka sengaja mengambil gambar dan video perayaan-perayaan seperti cap go meh bagi etnis tionghoa, naik dango bagi etnis dayak, musyawarah adat budaya melayu (MABM) yang biasanya berupa pameran-pameran budaya dan arsitektur masyarakat melayu. Dengan kecanggihan teknologi saat ini tidaklah sulit bagi kita untuk membagi pengetahuan tentang adat budaya multikultural ini keppada dunia. Ditingkat Sekolah Menengah Atas biasanya siswa dalam tahap dimana kreatifitas berkembang sangat maksimal.

Peneltian ini akan mengembangkan media video pembelajaran bahasa Indonesia berbasis pendidikan multikultural untuk membangun kerukunan antar etnis, pembelajaran seperti ini direncanakan akan dilaksanakan ditingkat Sekolah Menengah Atas (SMA). Dengan menggunakan video-video tempat wisata yang bernilai sejarah multikultural atau berisi cerita-cerita daerah, kearifan lokal guru dapat mengajak siswa untuk merasa bangga, saling menghargai, dan mencintai perbedaan. Dengan video siswa dapat memberikan respon dari apa yang mereka lihat dan dengar serta memaknai materi yang ada didalamnya dan membangun kerukunan antar etnis, maka dari itu Pengembangan Media Video Pembelajaran Bahasa Indonesia Berbasis Pendidikan 
Multikultural untuk Membangun Kerukunan antar Etnis pada Tingkat SMA di Kota Singkawang dianggap penting. Seiring dengan perkembangan ilmu pengetahuan dan teknologi semakin mendorong upaya-upaya pembaharuan dalam proses belajar mengajar. Para guru dituntut untuk agar mampu menggunakan berbagai alat yang tersedia di sekolah. Bahkan guru di tuntut untuk kreatif mengembangkan atau menciptkan media pembelajaran yang dapat mendukung proses pembelajaran dapat berjalan dengan baik. Menurut Arsyad (2011) menjelaskan bahwa media adalah bagian yang tidak terpisahkan dari proses belajar mengajar demi tercapainya tujuan pendidikan pada umumnya dan tujuan pembelajaran di sekolah pada khususnya.

Secara garis besar Gerlach dan Ely (1971) mengatakan bahwa media adalah manusia, materi atau kejadian yang membangun kondisi yang membuat siswa mempu emperoleh pengetahuan, keterampilan dan sikap. Dalam pengertian ini, guru, buku teks, dan lingkungan sekolah merupakan media. Berdasarkan hal tersebut media pembelajaran adalah sarana untuk meningkatkan dan mengarahkan perhatian siswa sehingga dapat menimbulkan motivasi belajar, interaksi yang lebih hidup dan memungkinkan siswa dapat memahami materi dengan lebih jelas.

Kemp dan Dauton (1985) mengelompokkan media kedalam delapan jenis, yaitu (1) media cetak, (2) media panjang, (3) overhead tranparacie, (4) rekaman audiotape, (5) seri slide dan filmstrips, (6) penyajian multi-image, (7) rekaman video dan film hidup, (8) komputer. Dari kedelapan jenis media pembelajaran yang dikemukakan oleh Kemp dan Dauton di atas, media video dapat dikatakan media yang paling menarik. Hal ini dikarenakan media video merupakan gambar hidup bergerak yang dapat diamati secara visual oleh siswa baik itu suasananya dan juga suara yang menyertainya.

Media video pembelajaran dalam proses pembuatannya harus disesuaikan dengan materi yang akan diajarkan. Selain kecocokan dengan materi target atau sasaran media video ini juga harus diperhatikan, karena nantinya media video pembelajaran ini akan disajikan kepada siswa. Oleh karena itu perencanaan dalam membuat video pembelajaran harus dilakukan secara matang.

Urgensi Pengembangan media video pembelajaran Bahasa Indonesia berbasis Pendidikan Multikultural untuk (1) membangun kerukunan antar etnis pada tingkat SMA di Kota Singkawang, (2)p ublikasi hasil penelitian pada jurnal jurnal nasional tidak terakreditasi dan jurnal nasional terakreditasi, (3) temuan ini menjadi dasar acuan untuk melakukan diseminasi atau proses penyebaran secara luas ke SMA di kota Singkawang, (4) temuan ini menjadi dasar penulisan buku teks yang berkaitan dengan penelitian dan pengembangan. Urgensi penelitian adalah membantu penelitian pengembangan media ajar video dengan berlandaskan pendidikan dalam masyarakat. Penelitian ini sangat diperlukan untuk pencegahan konflik horizontal di kalangan generasi muda yang sangat rentan terhadap pengaruh dari luar.

\section{METODE PENELITIAN}

Penelitian ini merupakan penelitian pengembangan dengan menggunakan model 4-D (Four-D Model) yang dikembangkan oleh Thiagarajan (2011) yang meliputi tahap pendefinisian (define), perencanaaan (design), pengembangan (develop), dan penyebaran (disseminate). Penelitian ini dilaksanankan 1 tahap dengan durasi waktu 1 tahun. Tahapan penelitian meliputi tahap pendefinisian (define), perencanaaan (design), pengembangan (develop), penyebaran (disseminate). 


\section{Prosedur Penelitian}

Prosedur dalam rrencana penelitian ini terdiri dari empat tahapa yaitu:

\section{Prosedur penelitian terdiri dari 4 Tahap Pendefinisian}

Tujuan tahap ini adalah untuk menetapkan dan mendefinisikan syarat-syarat pembelajaran. Tahap ini meliputi langkah-langkah yaitu : (a) analisis awal, analisis awal ini dilakukan dengan menganalisis masalah-masalah mendasar yang dihadapi dan perlu dijadikan sebagai bahan pertimbangan dalam pengembangan perangkat pembelajaran bahasa Indonesia berbasis pendidikan multikultural (b) analisis peserta didik, analisis peserta didik dilakukan untuk mengetahui karakteristik peserta didik di kota Singkawang yang sesuai dengan rancangan dan pengembangan bahan pelajaran, serta sesuai dengan sasaran penelitian; (c) analisis tugas, analisis ini mencakup analisis kurikulum yang meliputi silabus, standar kompetensi dan kompetensi dasar; (d) analisis konsep, analisis konsep meliputi analisis materi yang akan dibuatkan perangkat pembelajaran; (e) spesifikasi tujuan, perumusan tujuan pembelajaran disesuaikan dengan standar kompetensi dan kompetensi dasar dalam pembelajaran

\section{Tahap Perancangan}

Tahap ini meliputi langkah-langkah sebagai berikut: (a) penyusunan teks, (b) pemilihan media; (c) pemilihan format, (d) rancangan awal, pada tahap ini telah dikembangkan perangkat pembelajaran yang meliputi silabus pembelajaran (SP), rencana pelaksanaan pembelajaran (RPP), buku bacaan peserta didik (BBPD), dan lembar kerja peserta didik (LKPD), media pembelajaran dan instrumen penilaian untuk materi bahasa Indonesia.

\section{Tahap Pengembangan}

Tujuan tahap ini adalah untuk menghasilkan perangkat pembelajaran yang sudah direvisi berdasarkan masukan dari para pakar maupun setelah dilakukan uji coba. Adapun langkah- langkah dalam tahap pengembangan sebagai berikut: (a) validasi, validasi dilakukan untuk menguji perangkat yang dikembangkan apakah sudah memenuhi kriteria valid dan praktis berdasarkan penilaian validator dan praktisi, (b) Uji coba terbatas, tujuannya adalah untuk menguji kepratisan dan kefektifan perangkat yang dikembangkan, (c) Pengemasan

\section{Tahap penyebaran (Disseminate).}

Pada tahap ini merupakan tahap penggunaan perangkat yang telah dikembangkan pada skala yang lebih luas yaitu di SMA se kota Singkawang. Tempat penelitian ini akan dilaksanakan di beberapa SMA di kota Singkawang untuk penerapan media video pembelajaran Bahasa Indonesia yang berbasis Pendidikan Multikultural untuk membangun kerukunan antar etnis di Kota Singkawang. Populasi dan sampel penelitian ini dilakukan pada jenjang SMA di kota Singkawang yang memiliki karakteristik masyararakat multi etnis. Sampel dalam penelitian ini dilakukan tiga tahap uji lapangan terhadap produk sehingga ada tiga jenis sampel yang diambil. Pada ujicoba pada tahap pertama dan kedua menggunakan teknik purposive sampling, pada tahap ketiga menggunakan total sampling. 
Teknik Analisis Data diperoleh dari instrumen penilaian validator ahli dan praktisi dilakukan analisis sebagai berikut:

a. Pengkodean Responden

Penilaian responden dilakukan dengan memberikan skor berdasarkan ketentuan sebagai berikut:

Tabel 1. Koding Tanggapan Responden

\begin{tabular}{ccc} 
& Pernyataan Posi & Pernyataan Nega \\
\hline Sangat Setuju & 4 & 1 \\
\hline Setuju & 3 & 2 \\
\hline Kurang Setuju & 2 & 3 \\
\hline Tidak Setuju & 1 & 4 \\
\hline
\end{tabular}

b. Analisis Deskriptif Kuantitatif

Menghitung persentase tanggapan ahli dan peserta didik untuk setiap pernyataan dengan kriteria sebagai berikut:

Tabel 2. Kriteria Interpretasi Skor

\section{Persentase (\%) Kriteria}

\begin{tabular}{cl}
\hline $0-25$ Sangat & Kurang \\
$26-50$ & Kurang \\
$51-75$ & Baik \\
$76-100$ & Sangat Baik \\
\hline
\end{tabular}

\section{HASIL DAN PEMBAHASAN}

Media video pembelajaran dalam proses pembuatannya harus disesuaikan dengan materi yang akan diajarkan. Selain kecocokan dengan materi target atau sasaran media video ini juga harus diperhatikan, karena nantinya media video pembelajaran ini akan disajikan kepada siswa. Oleh karena itu perencanaan dalam membuat video pembelajaran harus dilakukan secara matang.

Pada penelitian ini bertujuan untuk menghasilkan produk media pembelajaran berbentuk video dengan mengadopsi langkah-langkah pengembangan model pengembangan dengan menggunakan model 4-D (Four-D dikembangkan oleh Thiagarajan (2011) yang meliputi tahap pendefinisian (define), perencanaaan (design), pengembangan (develop), dan penyebaran (disseminate):

\section{Tahap Pendefinisian}

Tujuan tahap ini adalah untuk menetapkan dan mendefinisikan syarat-syarat pembelajaran. Tahap ini meliputi langkah-langkah yaitu : (a) analisis awal, analisis awal ini dilakukan dengan menganalisis masalah-masalah mendasar yang dihadapi dan perlu dijadikan sebagai bahan pertimbangan dalam pengembangan perangkat pembelajaran 
bahasa Indonesia berbasis pendidikan multikultural (b) analisis peserta didik, analisis peserta didik dilakukan untuk mengetahui karakteristik peserta didik di kota Singkawang yang sesuai dengan rancangan dan pengembangan bahan pelajaran, serta sesuai dengan sasaran penelitian;(c) analisis tugas,analisis ini mencakup analisis kurikulum yang meliputi silabus, standar kompetensi dan kompetensi dasar;(d)analisis konsep, analisis konsep meliputi analisis materi yang akan dibuatkan perangkat pembelajaran; (e) spesifikasi tujuan, perumusan tujuan pembelajaran disesuaikan dengan standar kompetensi dan kompetensi dasar dalampembelajaran

Pada tahap ini peneliti menggunakan teknik observasi dan wawancara yang dilakukan terhadap guru dan pengampu mata pelajaran bahasa Indonesia di SMA. Proses kegiatan ini dilakukan guna mendapatkan informasi mengenai proses pembelajaran, karakteristik siswa, tujuan pembelajaran, media pembelajaran yang tersedia, serta informasi lainnya yang mendukung dalam pembuatan media video pembelajaran. Dari kegiatan ini diperoleh beberapa data sebagai berikut:

a) Kurikulum yang digunakan di SMA di kota Singkawang yaitu Kurikulum 2013. Pada Bahasa Indonesia, fokus kajiannya mengenai masyakarat multi etnis. Sementara pada proses pembelajarannya menggunakan pendekatan scientific yang berpusat kepada siswa. Selain itu, tujuan dari mata pelajaran tersebut adalah memberikan pemahaman terhadap pola masyarakat yang multi etnis, multi budaya dan multi agama dan kepercayaan melalui teks eksposisi. Melalui pemahaman tersebut diharapkan akan menumbuhkan penghormatan dan penghargaan akan keanekaragaman tersebut dalam perspektif kebahasaan.

b) Tidak adanya video yang secara khusus membahas mengenai pendidikan multikultural dalam proses pembelajaran. Namun dalam penyampaian materi guru menggunakan laptop dengan memanfaatkan aplikasi power point untuk menampilkan materi dalam bentuk gambar dan teks. Hal ini yang memungkinkan dilakukan pengembangan media pembelajaran dalam bentuk video agar siswa bisa melihat secara nyata keragaman masyakarat Singkawang yang multi etnis dan multi agama.

c) Tersedianya sarana dan prasarana yang menunjang disetiap kelas memungkinkan proses pembelajaran menggunakan media video baik itu infocus, proyektor, dan sound system. Adanya sarana tersebut video pembelajaran video ajar bahasa Indonesia berbasis pendidikan multikultural dapat diputar di kelas.

Dari data yang diperoleh hasil observasi dan wawancara, peniliti bermaksud untuk mengembangkan media video pembelajaran Bahasa Indonesia Berbasis Pendidikan Multikultural Untuk Membangun Kerukunan Antar Etnis Pada Tingkat SMA di Kota Singkawang yang dapat membantu siswa dalam proses pembelajaran. Setelah proses observasi dan wawancara dilakukan, kegiatan berikutnya mengumpulkan sumbersumber untuk dijadikan referensi seperti kurikulum, silabus, materi, dan buku-buku referensi lainnya seperti teori belajar dan pembelajaran, teori dan praktek mengenai media pembelajaran dan pembuatan video menggunakan Adobe Premiere CS6, serta mengisntal sofware pendukung seperti Google Aerth Pro dan Windows Moviemaker. Selanjutnya diteruskan dengan proses pembuatan materi yang dirancang pada tahap design yang nantinya akan menjadi pedoman dalam pembuatan video pembelajaran bahasa Indonesia berbasis Pendidikan Multikultural.

Dari temuan-temuan yang dijelaskan diatas dapat disimpulkan dalam proses pembelajaran memiliki kendala yang dihadapi. Namun, ada point penting yang perlu 
diperhatikan bahwa guru bahasa Indonesia di SMA 1, SMA 2, dan SMA 3 mata pelajaran bahasa Indonesia telah menggunakan media pembelajaran dalam menyampaikan materi dengan bantuan laptop, serta telah memiliki sarana yang menunjang untuk pemutaran video pembelajaran di kelas dan individu.

Analisa materi yaitu dengan cara mengidentifikasi kemampuan akhir yang diharapkan yang tertera pada silabus dalam kurikulum SMA. Dari identifikasi tersebut maka didapatkan materi yang akan dimasukkan dalam media pembelajaran dan disusun secara sistematis untuk disajikan pada media video pembelajaran bahasa Indonesia berbasis pendidikan multikultural dan membangun kerukunan etnis di kota Singkawang.

\section{Tahap Perancangan}

Tahap ini meliputi langkah-langkah sebagai berikut: (a) penyusunan teks, (b) pemilihan media; (c) pemilihan format, (d) rancangan awal, pada tahap ini telah dikembangkan perangkat pembelajaran yang meliputi video ajar. Pada tahap ini merupakan tahap perancangan media pembelajaran sebelum dilakukan pada laptop atau komputer. Dalam membangun sistem dan untuk merealisasikannya sistem tersebut terlebih dahulu dibuat alur dari video yang akan dikembangkan, setelah itu membuat storyboard untuk menjadi panduan dalam pembuatan video pembelajaran.

\section{Data Hasil Evaluasi Produk Tim Ahli Media dan Materi}

Media Video Pembelajaran sebelum di uji cobakan diberi penilaian terlebih dahulu oleh tim ahli yang terdiri dari ahli media dan ahli materi oleh Dr Martono. Data dari tim ahli tersebut berupa penilaian mengenai aspek-aspek dan data berupa saran atau komentar guna perbaikan yang dapat dilihat Pada tabel dibawah ini.

a) Data Tim Ahli Media

Penilaian, komentar beserta saran untuk media video pembelajaran bahasa Indonesia berbasis Pendidikan Mutikultural untuk membangun kerukunan etnis di kota Singkawang. Data hasil penilaian tersebut dapat dilihat pada tabel dibawah ini.

Tabel 4.3 Data Hasil Penilaian Media Video Pembelajaran Bahasa Indonesia berbasis Pendidikan Multikutural untuk membangun kerukunan etnis di kota Sinkawang Oleh Ahli Media

\begin{tabular}{|c|c|c|c|}
\hline No & Aspek & $\begin{array}{c}\text { Rerata } \\
\text { Skor }\end{array}$ & Kategori \\
\hline 1 & Komunikasi & 4.5 & Baik \\
\hline 2 & Teknis & 4 & Baik \\
\hline 3 & Tampilan & 4 & Baik \\
\hline \multicolumn{2}{|l|}{ Rata- rata } & $\mathbf{4 . 1}$ & Baik \\
\hline
\end{tabular}

Dari tabel diatas diketahui hasil penilaian oleh ahli media untuk aspek komunikasi diperoleh rerata skor 4.5 tergolong kategori "baik", aspek teknis diperoleh rerata skor 4 dengan kategori "baik", dan pada aspek tampilan diperoleh rerata skor 4 pada kategori "baik". Total keseluruh dari aspek pada penilaian media adalah 12.5 dengan kategori "Baik".

Sementara pada bagian Saran atau komentar yang diberikan oleh ahli materi seperti pada tabel berikut ini. 
Tabel 4.4 Data Saran / Komentar Oleh Ahli Media

\begin{tabular}{|r|l|}
\hline No & \multicolumn{1}{c|}{ Saran Atau Komentar } \\
\hline 1 & Harus ada tujuan pembelajaran \\
\hline 2 & $\begin{array}{l}\text { Slipkan foto/gambar/video temuan lain yang unik pada masyarakat } \\
\text { kota Singkawang }\end{array}$ \\
\hline 3 & Suara materi dibeberapa bagian menit tersendat \\
\hline 4 & Musik latar diperkecil saat suara penyampaian materi \\
\hline 5 & Perbaiki pada transisi video \\
\hline 6 & $\begin{array}{l}\text { Pada dasarnya video sudah bagus dan layak untuk di uji cobakan di } \\
\text { beberapa SMA di kota Singkawang }\end{array}$ \\
\hline
\end{tabular}

b) Data Tim Ahli Materi

Penilaian, komentar beserta saran pada materi yang terdapat di video pembelajaran bahasa Indonesia berbasis pendidikan multiKultural untuk membangun kerukunan etnis di kota Singkawang dilakukan oleh Dr. Martono. Total keseluruh dari aspek pada penilaian materi adalah 4.1 dengan kategori “ Baik".

Sementara pada bagian Saran atau komentar yang diberikan oleh ahli materi seperti pada tabel berikut ini.

Tabel 4.6 Data Saran/komentar Ahli Materi

\begin{tabular}{|l|l|}
\hline No & \multicolumn{1}{c|}{ Saran dan Komentar } \\
\hline 1 & Kelengkapan materi kurang teliti \\
\hline 2 & Kejelasan materi dibuat sederhana \\
\hline 3 & Materi sesuaikan dengan tujuan pembelajaran bahasa Indonesia \\
\hline 4 & $\begin{array}{l}\text { Tampilkan juga beragam aspek lain tentang masyarakat multikultural di } \\
\text { kota Singkawang }\end{array}$ \\
\hline 5 & $\begin{array}{l}\text { Silahkan di uji cobakan setelah adanya perbaikan dari saran yang } \\
\text { telah diberikan. }\end{array}$ \\
\hline
\end{tabular}

Pengembangan video dilakukan di Sekolah Menengah Atas, fokus kajiannya pada teks eksposisi dengan melihat video ajar bahasa Indonesia. Di dalam pembelajaran yang berpusat pada siswa maka guru sebagai fasilitator perlu mempersiapkan dan merencanakan pembelajaran termasuk dalam menentukan media pembelajararan yang tepat. Pembelajaran bahasa Indonesia menggunakan laptop dengan memanfaatkan aplikasi power point untuk menampilkan materi dalam bentuk gambar dan teks, media tersebut masih dalam bentuk media visual dan belum menggunakan media audio visual salah satu contohnya adalah media video. Guruharus menggunakan media pembelajaran yang bervariasi dan inovatif. karna media pembelajaran merupakan salah satu alat bantu untuk memudahkan pesan dalam materi perkuliahan tersampaikan kepada mahasiswa secara optimal. Media video merupakan media audio visual dimana terdapat gambar maupun suara sehingga mahasiswa dapat mendengar dan melihat secara langsung kehidupan masyarakat Singkawang yang beragam dan multi etnis, menurut Hamalik (Dalam 
Azhar Arsad, 2013: 19) mengemukakan bahwa pemakaian media pembelajaran dalam proses pembelajaran dapat membangkitkan keinginan dan minat yang baru, membangkitkan motivasi dan rangsangan kegiatan belajar, dan bahkan membawa pengaruh-pengaruh psikologis terhadap peserta didik.

Singkawang merupakan salah satu kota yang memilik karakteristik masyarakat yang majemuk karena karakteristik masyarakat yang multietnik yaitu terdiri dari aneka ragam suku-bangsa, adat, agama dan kebudayaan. Namun, bagai dua sisi mata uang yang berbeda, masih dalam satu kesatuan, kondisi masyarakat yang majemuk tersebut dapat dilihat dalam dua hal yang berbeda pula, disatu sisi kemajemukan tersebut dipandang sebagai suatu kekayaan budaya bangsa, disisi lain dengan keadaan masyarakat yang berbeda-beda adat, kebiasaan dan budaya yang beragam tersebut berpotensi menimbulkan konflik, yakni konflik suku, agama, dan ras (SARA).

Sebagian besar penduduk Kota Singkawang beragama Budha yang kebanyakan dianut oleh penduduk dari etnis China. Umat Budha ini tersebar diseluruh kecamatan, terbanyak berada di Kecamatan Singkawang Barat dan Selatan. Penduduk beragama Islam merupakan yang terbesar kedua, tersebar dilima kecamatan, terbanyak berada di Kecamatan Singkawang Tengah. Menyusul diurutan ketiga dan keempat masing-masing penduduk beragama Katolik dan Protestan yang umumnya berada merata di Kecamatan Timur, Tengah, Barat dan Selatan. Penduduk beragama Hindu merupakan jumlah penganut agama terkecil tersebar di empat kecamatan yaitu Kecamatan Singkawang Tengah, Singkawang Barat, Singkawang Utara dan Singkawang Selatan.

Oleh karena, adanya media pembelajaran yang berbasis pendidikan multikultural berupa video pembelajaran bahasa Indonesia yang bertujuan untuk membangun kerukunan antar etnis di Singkawang. Hal yang dilakukan terlebih dahulu sebelum mengembangkan media video ajar bahasa Indonesia adalah melakukan analisis, menentukan desain pembelajaran untuk mengembangkan media pembelajaran, mengumpulkan materi dari berbagai kajian literature, mengumpulkan bahan-bahan yang akan digunakan untuk membuat media berupa rekaman video masyarakat, membuat storybord,dan mencari musik sebagai pengiring tampilan video. Selanjutnya sesuai dengan landasan teknologis, pengembangan media pembelajaran bahasa Indonesia berbasis media audio visual dengan menggunakan aplikasi atau software pembuat video berupa adobe premiere CS6. Langkah selanjutnya yaitu memadukan materi yang bersal dari kajian literature yang telah didapat dengan rekaman video kedalam aplikasi Adobe Premiere CS6 tersebut, setelah dipadukan antara materi dengan video sudah sesuai kemudian dimasukkan musik pengiring video tersebut. Setelah semua selesai dipadukan dan dinilai sudah cukup sistematis, kemudian video yang disimpan di dalam komputer diburning ke dalam CD yang nantinya produk ini dapat diimplementasikan dalam proses pembelajaran.

Untuk menambahkan konten materi sesuai saran dari ahli materi, maka peneliti menambahkan materi- materi untuk mempertebal toleransi.Setelah video pembelajaran direvisi dan divalidasi oleh tim ahli selanjutnya video di uji cobakan ke siswa.

\section{KESIMPULAN}


Kerukunan antar etnis adalah salah satu kunci utama dalam menciptakan persatuan Indonesia, seperti yang tertuang dalam salah satu sila pancasila yaitu sila ketiga. Sikap menghargai sangat diperlukan dalam memupuk kerukunan masyarakat Indonesia yang multukutur, terutama bagi generasi muda yang sangat rawan melakukan tindakan anarkis. Hasil penilaian oleh ahli media untuk aspek komunikasi diperoleh rerata skor 4.5 tergolong kategori "baik", aspek teknis diperoleh rerata skor 4 dengan kategori "baik", dan pada aspek tampilan diperoleh rerata skor 4 pada kategori "baik". Total keseluruh dari aspek pada penilaian media adalah 12.5 dengan kategori "Baik". Penelitian ini masih dalam tahap penyusunan produk, yaitu dalam bentuk video. Sehingga penelitian ini masih perlu dilanjutkan dengan uji kelayakan dilapangan sebagaimana tahapan penelitian pengembangan seharusnya. Setelah semua langkah-langkah penelitian pengembangan diakukan baru lengkaplah suatu penelitian pengembangan sesuai dengan rencana penelitian.

\section{UCAPAN TERIMA KASIH}

Peneliti menyampaikan ucapan terima kasih kepada DIKTI selaku pemberi sponsor sehingga penelitian ini dapat dilakukan dan akan terlaksana secara penuh. Ucapan terima kasih juga disampaikan kepada Dinas Pendidikan Kota Singkawang yang telah memberikan izin untuk dilaksanakan penelitian.

\section{REFERENSI}

Andersen dan Cusher, "Multicultural and Intercultural Studies" dalam C. Marsh (ed), Teaching Studies of Society and Environment ( Sydney: Prentice-Hall, 1994).

Arsyad, Azhar. 2011. Media Pembelajaran. Jakarta: Raja Grafindo Persada.

Banks, James A. "Chapter 1: Multicultural education: Historical development, dimensions, and practice." Review of research in education 19.1 (1993): 3-49.

Gerlach, V.G. dan Ely, D.P. 1971. Teaching and Media. A Sistematic Approach. Englewood Cliffs: Prentice-Hall, Inc.

Kemp, J.E. dan Dauton, D.K. 1985. Planning and Producing Instructional Media (Fifth Edition). New York: Harper \& Row, Publishers.

Purwahida, R. (2017). Interaksi sosial pada kumpulan cerpen Potongan Cerita di Kartu Pos karangan Agus Noor dan implikasinya terhadap pembelajaran sastra di SMA. Aksis: Jurnal Pendidikan Bahasa dan Sastra Indonesia 1(1). 118-134. doi: doi.org/10.21009/AKSIS.010107

Reka Seprina, 2013. "Pengembangan Pembelajaran Sejarah Lokal Berbasis Media Animasi Untuk Meningkatkan Kesadaran Budaya Siswa SMP N 1 Surakarta". Surakarta : Tesis UNS.

Suhita, S., \& Purwahida, R. (2018). Apresiasi Sastra Indonesia dan Pembelajarannya. Bandung: Remaja Rosdakarya. 
Tesis Aurora (2015, UNS) dalam penelitiannya dengan judul "Pengembangan Media Pembelajaran Sejarah Berbasis Audio Visual Situs Purbakala Pugung Raharjo Untuk Meningkatkan Kesadaran Sejarah Siswa Kelas X SMA Negeri 1 Kota Gajah

Thiagarajan, S. Sempmel, D.S. and Sammel, M.I. (1974). Instruction Development for Training Teachers of Exeptionaf Children. Indiana: Indiana University Bloominton. 